\title{
Expression of Bitter Taste Receptors in the Human Skin In Vitro
}

Edyta Reszka ${ }^{1}$, Ewa Nowakowska-Świrta ${ }^{2}$, Maciej Kupczyk ${ }^{3}$, Wojciech Dudek ${ }^{2}$, Dominika Świerczyńska-Machura ${ }^{\star}$, Tomasz Wittczak ${ }^{2}$, Jan Rykała ${ }^{4}$, Monika Przybek $^{1}$, Ewa Jabłońska ${ }^{1}$, Beata Kręcisz ${ }^{2}$, Piotr Kuna ${ }^{3}$, Wojciech Wąsowicz ${ }^{1}$ and Cezary Pałczyński ${ }^{2,3}$

${ }^{1}$ Department of Toxicology and Carcinogenesis, Nofer Institute of Occupational Diseases, Łódź, Poland

${ }^{2}$ Department of Allergology and Environmental Health, Nofer Institute of Occupational Diseases, Łódź, Poland

${ }^{3}$ Department of Internal Diseases, Asthma and Allergy, Medical University of Łódź, Poland

${ }^{4}$ Department of Plastic Reconstructive and Aesthetic Surgery, Medical University of Łódź, Poland

"Corresponding author: Dominika Świerczyńska-Machura, Department of Allergology and Environmental Health, Nofer Institute of Occupational Medicine, Poland, Tel: 48426314798; 48426314764; E-mail: mika@imp.lodz.pl

Rec date: Feb 23, 2015, Acc date: Apr 01, 2015, Pub date: Apr 05, 2015

Copyright: (C) 2015 Reszka E, et al. This is an open-access article distributed under the terms of the Creative Commons Attribution License, which permits unrestricted use, distribution, and reproduction in any medium, provided the original author and source are credited.

Keywords: Bitter taste receptors; Skin; Tastants

\section{Letter to the Editor}

Human bitter taste is mediated by the hTAS2R family of G-protein coupled receptors [1]. The main function of these receptors but to date never has been proved sufficiently is to protect the organism against ingestion of toxic substances [2]. A number of studies have been performed to the analyse TAS2R gene expression in gustatory and, more recently, in extragustatory tissues of rodents and humans [3]. Cells that express signalling components related to the TAS2R system have been found, among others in nasal respiratory epithelium, human airway smooth muscle, gastrointestinal tract and several other tissues [2,4-6]. TAS2Rs are present in some gastrointestinal endocrine cells, including those that secrete the peptide hormones (e.g. cholecystokinin, ghrelin and glucagons-like pepitide-1). Thus TAS2Rs may regulate metabolism, satiety, gastric empting, and the processing and absorption of ingested foods and pharmaceuticals [7]. Bitter tastants caused relaxation of isolated airway smooth muscle and dilation of airways that was threefold greater than elicited by betaadrenergic receptor agonists [5]. Thereby providing new treatment strategies for asthma and COPD. Moreover transcriptome analysis revealed upregulation of bitter taste receptors in white blood cells in children with severe, therapy-resistant asthma [8]. TAS2Rs are also connected with the ability to detect and respond to gram-negative bacteria such as Pseudomonas aeruginosa in the upper respiratory tract [9]. Finally the TAS2R genetic polymorphisms seem to play a role in the human longevity [10]. An interesting hypothesis was presented by Clark et al. that could explain many off-target effects of diverse pharmaceuticals [11]. They proposed that any drug with a bitter taste could have unintended actions in the body through stimulation of extraoral TAS2Rs. New evidence strongly suggests that TAS2R system play a much broader role in human health and they are present in "barrier" tissues and organs. Thus the goal of our study was to examined the expression of TAS2R in the human skin of facial area of healthy donors who underwent elective surgery due to esthetic reasons.

We analyzed expression patterns of all twenty five TAS2R transcripts from facial skin biopsies from 15 healthy volunteers (10 women and 5 men, mean aged $58 \pm$ 19.23). The Ethics Committee for Scientific Research at Nofer Institute approved the study protocol, and a written informed consent was obtained from each participant before taking part in the study. Each patient was given 1\% Lidocaine for local infiltration anesthesia. The incision was carried down through the skin and dermis using the scalpel. The $1 \mathrm{~cm}^{2}$ specimen was grasped using toothed forceps and was dissected out circumferentially and excised. All skin specimens were immediately stored in RNAlater reagent and then were stored at $-80^{\circ} \mathrm{C}$ until mRNA PCR analysis. Total RNA was isolated with AllPrep DNA/RNA Mini Kit (Qiagen, Hilden, Germany) including DNase digestion during RNA purification.

Transcript levels in skin biopsy were determined by means of quantitative real-time PCR (qPCR). Primers for target genes were designed with Beacon Designer 7.0 (PREMIER Biosoft Int., Palo Alto, CA, USA) according to GenBank' genetic sequence database. The cDNA was synthesized on 500 ng RNA with Quantitect Kit (Qiagen, Hilden, Germany). PCR efficiencies were calculated using dilutions of three randomly selected pooled cDNA samples. All the samples were amplified in duplicate. Expression was quantified with FastStart SYBR Green Master (Roche, Basel, Switzerland) and using $\beta$-glucuronidase (GUSB) as the endogenous control. Data obtained from qPCR were evaluated by Pfaffl method [12] with reference gene-normalized relative quantification with efficiency correction using qbasePLUS software (Version: 2.3) (Biogazelle NV, Zwijnaarde, Belgium).

Human skin biopsies expression of the gene transcripts of twenty three TAS2Rs is summarized in Figure 1. GUSB reference gene presents stable expression in human skin specimens [13]. Gene expression was estimated according to Pfaffl method with qRT-PCR efficiency correction. All transcripts were found expressed in all patients, except $T A S 2 R 7,8,9,20,38$ and 39 which were found in specimens from $13 / 15,9 / 15,13 / 15,11 / 15,9 / 15$ and 10/15 patients only. TAS2R1 and TAS2R16 showed lack of mRNA expression in human skin biopsies. Study on human keratinocyte cell line HaCaT revealed expression of $T A S 2 R 1$ and $T A S 2 R 38$ receptors at protein level, which is in conflict in our results [14]. To add TAS2R1 and $T A S 2 R 38$ gene expression was also found in breast cancer epithelial cells [15]. In contrast human airway smooth muscle presented very low mRNA expression of TAS2R1 and non-detectable expression of TAS2R38 [5].

In summary we have demonstrated expression of TAS2Rs in the human skin and to our knowledge this is the first report of this expression. TAS2Rs expression pattern in skin biopsies was different than observed in human blood leukocytes, which may exclude blood contamination of skin specimens [16]. Surprisingly, TAS2R31-bitter taste receptor with the highest expression in skin among 25 known human TAS2Rs (Figure 1), revealed the highest relative RNA expression in various subpopulations of circulating leukocytes. It has been shown that TAS2Rs were differentially expressed in different cell types, and their expression was associated with the age [17] of analysed patients and also with undergoing pathologies [18]. Similarly in our 
Citation: Reszka E, Nowakowska-Swirta E, Kupczyk M, Dudek W, Swierczynska-Machura D, et al. (2015) Expression of Bitter Taste Receptors in the Human Skin In Vitro. J Clinic Res Bioeth 6: 218. doi:10.4172/2155-9627.1000218

Page 2 of 2

study the pattern of expression of TAS2Rs is different to the one observed in isolated mixed leukocytes, lymphocytes, monocytes and neutrophils in adult human asthmatics [8]. Specific pattern of TAS2Rs was also found in mammary epithelial cells with some TAS2Rs downregulated in breast cancer cells [15]. Additionally, we should consider that selective TAS2Rs expression in different specimens may indicate presence of gene variants [19]. Further studies on the expression of these receptors and their potential role in the maintenance of homeostasis, in health and disease including carcinogenesis, acute and chronic inflammation are warranted. The usefulness of the discovery of TAS2R expression in human skin in clinical practise is difficult to predict but it could be the novel therapy of IgE-mediated skin diseases by TAS2R antagonists [20].

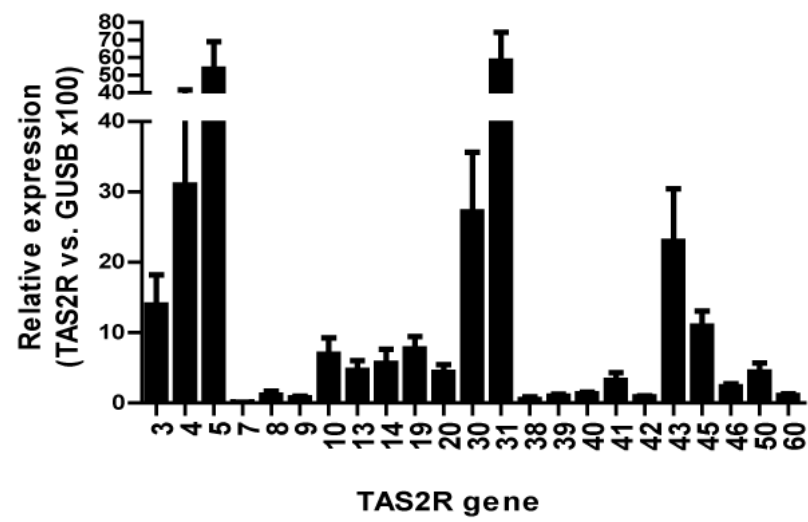

Figure 1: Relative expression of genes encoding for bitter taste receptors: TAS2R3, 4, 5, 7, 8, 9, 10,14,19, 20, 30, 31, 38, 39, 40, 41, $42,43,45,46,50,60$ gene transcripts in human skin biopsies. Values are expressed as mean \pm SEM.

\section{Conflict of Interest}

The authors state no conflict of interest.

\section{References}

1. Chandrashekar J, Mueller KL, Hoon MA, Adler E, Feng L, et al. (2000) T2Rs function as bitter taste receptors. Cell 100: 703-711.

2. Behrens M, Meyerhof W (2011) Gustatory and extragustatory functions of mammalian taste receptors. Physiol Behav 105: 4-13.

3. Pydi SP, Upadhyaya J, Singh N, Pal Bhullar R, Chelikani P (2012) Recent advances in structure and function studies on human bitter taste receptors. Curr Protein Pept Sci 13: 501-508.

4. Finger TE, Böttger B, Hansen A, Anderson KT, Alimohammadi H, et al. (2003) Solitary chemoreceptor cells in the nasal cavity serve as sentinels of respiration. Proc Natl Acad Sci U S A 100: 8981-8986.
5. Deshpande DA, Wang WC, McIlmoyle EL, Robinett KS, Schillinger RM, et al. (2010) Bitter taste receptors on airway smooth muscle bronchodilate by localized calcium signaling and reverse obstruction. Nat Med 16: 1299-1304.

6. Wu SV, Rozengurt N, Yang M, Young SH, Sinnett-Smith J, et al. (2002) Expression of bitter taste receptors of the T2R family in the gastrointestinal tract and enteroendocrine STC-1 cells. Proc Natl Acad Sci U S A 99: 2392-2397.

7. Janssen S, Laermans J, Verhulst PJ, Thijs T, Tack J, et al. (2011) Bitter taste receptors and $\alpha$-gustducin regulate the secretion of ghrelin with functional effects on food intake and gastric emptying. Proc Natl Acad Sci U S A 108: 2094-2099.

8. Orsmark-Pietras C, James A, Konradsen JR, Nordlund B, Söderhäll C, et al. (2013) Transcriptome analysis reveals upregulation of bitter taste receptors in severe asthmatics. Eur Respir J 42: 65-78.

9. Lee RJ, Xiong G, Kofonow JM, Chen B, Lysenko A, et al. (2012) T2R38 taste receptor polymorphisms underlie susceptibility to upper respiratory infection. J Clin Invest 122: 4145-4159.

10. Campa D, De Rango F, Carrai M, Crocco P, Montesanto A, et al. (2012) Bitter taste receptor polymorphisms and human aging. PLoS One 7: e45232.

11. Clark AA, Liggett SB, Munger SD (2012) Extraoral bitter taste receptors as mediators of off-target drug effects. FASEB J 26: 4827-4831.

12. Pfaffl MW (2001) A new mathematical model for relative quantification in real-time RT-PCR. Nucleic Acids Res 29: e45.

13. Weinkauf B, Rukwied R, Quiding H, Dahllund L, Johansson P, et al. (2012) Local gene expression changes after UV-irradiation of human skin. PLoS One 7: e39411.

14. Wölfle U, Elsholz FA, Kersten A, Haarhaus B, Müller WE, et al. (2015) Expression and Functional Activity of the Bitter Taste Receptors TAS2R1 and TAS2R38 in Human Keratinocytes. Skin Pharmacol Physiol 28: 137-146.

15. Singh N, Chakraborty R, Bhullar RP, Chelikani P (2014) Differential expression of bitter taste receptors in non-cancerous breast epithelial and breast cancer cells. Biochem Biophys Res Commun 446: 499-503.

16. Malki A, Fiedler J, Fricke K, Ballweg I, Pfaffl MW, et al. (2015) Class I odorant receptors, TAS1R and TAS2R taste receptors, are markers for subpopulations of circulating leukocytes. J Leukoc Biol 97: 533-545.

17. Mennella JA, Reed DR, Roberts KM, Mathew PS, Mansfield CJ (2014) Age-related differences in bitter taste and efficacy of bitter blockers. PLoS One 9: e103107.

18. Lee RJ, Cohen NA (2015) Taste receptors in innate immunity. Cell Mol Life Sci 72: 217-236.

19. Hayes JE, Wallace MR, Knopik VS, Herbstman DM, Bartoshuk LM, et al. (2011) Allelic variation in TAS2R bitter receptor genes associates with variation in sensations from and ingestive behaviors toward common bitter beverages in adults. Chem Senses 36: 311-319.

20. Ekoff M, Choi JH, James A, Dahlén B, Nilsson G, et al. (2014) Bitter taste receptor (TAS2R) agonists inhibit IgE-dependent mast cell activation. J Allergy Clin Immunol 134: 475-478. 